\title{
PENGARUH LINGKUNGAN KERJA DAN DISIPLIN KERJA TERHADAP KINERJA PEGAWAI DINAS PENDIDIKAN KABUPATEN KARO
}

\author{
Veramika Br Sembiring ${ }^{1)}$, Hernayanti Br Barus ${ }^{2)}$, Kristina Nduru ${ }^{3)}$, Erni Sinaga ${ }^{4)}$, Rifka \\ Br Ginting ${ }^{5)}$
}

Fakultas Ekonomi Universitas Darma Agung ${ }^{1,2,3,4,5,}$

E-Mail:veramikas@gmail.com ${ }^{1 *}$

\begin{abstract}
Abstrak :Penelitian ini bertujuan untuk mengetahui pengaruh parsial maupun simultan disiplin kerja dan lingkungan kerja terhadap kinerja pegawai Dinas Pendidikan Kabupaten Karo. Penelitian ini termasuk penelitian kuantitatif, dimana instrumen penelitian ini berupa kuesioner. Populasi dan sampel dalam penelitian ini adalah seluruh pegawai Dinas Pendidikan Kabupaten Karo yaitu sebanyak 42 orang. Uji instrumen pada penelitian ini dilakukan dengan menggunakan uji validitas dan reliabilitas. Teknik analisis data dalam penelitian ini menggunakan teknik analisis regresi linier berganda. Hasil penelitian diperoleh bahwa lingkungan kerja berpengaruh positif dan signifikan terhadap kinerja pegawai, dimana nilai $\mathrm{t}$ hitung $(2,452)$ lebih besar dari nilai t tabel $(2,015)$, dan nilai signifikansinya sebesar 0,019 lebih kecil dari 0,05. Disiplin kerja berpengaruh positif dan signifikan terhadap kinerja pegawai, dimana nilai $\mathrm{t}$ hitung $(6,670)$ lebih besar dari nilai t tabel $(2,015)$, dan nilai signifikansinya sebesar 0,000 lebih kecil dari 0,05. Lingkungan kerja dan disiplin kerja secara bersama-sama berpengaruh positif dan signifikan terhadap kinerja pegawai, dimana nilai $\mathrm{F}$ hitung $(33,789)$ lebih besar dari nilai $F$ tabel $(2,83)$, dan nilai signifikansinya sebesar 0,000 lebih kecil dari 0,05. Besarnya pengaruh variabel bebas (lingkungan kerja dan disiplin kerja) terhadap variabel terikatnya (kinerja pegawai) sebesar $63,4 \%$, sedangkan sisanya sebesar $36,6 \%$ dipengaruhi oleh faktor lain yang tidak diteliti dalam penelitian ini.
\end{abstract}

Kata Kunci : disiplin kerja, lingkungan kerja, dan kinerja pegawai

\section{The Effect Of Work Environment and Discipline of Work on Performance Of Employees DINAS PENDIDIKAN KABUPATEN KARO}

\author{
Veramika Br Sembiring ${ }^{1)}$, Hernayanti Br Barus ${ }^{2)}$, Kristina Nduru ${ }^{3)}$, Erni Sinaga ${ }^{4)}$, Rifka \\ Br Ginting ${ }^{5)}$ \\ Fakultas Ekonomi Universitas Darma Agung 1,2,3,4,5) \\ E-Mail:veramikas@gmail.com ${ }^{1)^{*}}$
}

\begin{abstract}
This study aims to determine the partial and simultaneous effect of work discipline and work environment on the performance of Dinas Pendidikan Kabupaten Karo. This research is a quantitative research, where the research instrument is a questionnaire. The population and sample in this study were all employees of the Dinas Pendidikan Kabupaten Karo as many as 42 people. Instrument testing in this study was conducted using validity and reliability tests. The data analysis technique in this study uses multiple linear regression analysis techniques. The results showed that the work environment has a positive and significant effect on employee performance, where the $t$ value (2.452) is greater than the $t$
\end{abstract}


table value (2.015), and the significance value is 0.019 less than 0.05. Work discipline has a positive and significant effect on employee performance, where the $t$ value (6.670) is greater than the t table value (2.015), and the significance value is 0.000 less than 0.05 . Work environment and work discipline together have a positive and significant effect on employee performance, where the calculated $F$ value (33.789) is greater than the $F$ table value (2.83), and the significance value is 0.000 less than 0.05. The amount of influence of the independent variables (work environment and work discipline) on the dependent variable (employee performance) is $63.4 \%$, while the remaining $36.6 \%$ is influenced by other factors not examined in this study.

Keywords: work discipline, work environment, and employee performance

\section{PENDAHULUAN}

Setiap organisasi atau perusahaan mempunyai lingkungan yang unik, maka perlu ada penyesuaian atas konten budayanya. Setiap perusahaan unik relatif terhadap lingkungan, dan sebuah perusahaan baru dapat memanfaatkan kekuatan budaya dan meningkatkan keefektifan organisasi ketika konten itu sejalan dengan lingkungan kerja.

Selain lingkungan kerja, masalah disiplin kerja pun ikut meningkatkan kinerja pegawai. Kedisiplinan mengacu pada kegiatan proses atau sistem kerja mulai dari pegawai masuk dan kembali pulang tepat waktunya, mengerjakan semua pekerjaan dengan sungguhsungguh, taat kepada aturan yang berlaku di perusahaan serta budaya kerja yang ada.

Seseorang yang memiliki kedisiplinan kerja yang baik atau kuat akan mempunyai keyakinan bahwa kerja dengan sungguh-sungguh merupakan kiat menuju sukses dan meraih kebahagiaan. Dari beberapa pendapat ahli yang ada, terungkap bahwa individu yang menerapkan disiplin kerja yang maksimal punya kesadaran dan kesediaan yang dimana suatu perilaku, tingkah laku dan perbuatan akan memiliki gagasan/ide, memperoleh kenyamanan dalam bekerja, produktif, berprestasi dan mempunyai keyakinan yang baik.

Dinas Pendidikan Kabupaten Karo didirikan dengan tujuan kewenangan daerah dalam sektor Pendidikan. Dalam menjalankan tujuannya, Dinas Pendidikan Kabupaten Karo memiliki beberapa tugas diantaranya merumuskan kebijakan teknis dalam sektor Pendidikan. Penyusunan dan pelaksanaan rencana kerja di sektor pendidikan, penerapan kurikulum pendidikan, metode pengadaan dan pemeliharaan sarana dan prasarana pendidikan, pembinaan dan pengawasan tenaga fungsional pendidikan, pembinaan, pengawasan, dan pengelolaan serta pemberian penghargaan kepada para pendidik, pelaksanaan tugas lain yang diberikan oleh Bupati yang sejalan dengan tupoksinya.

Untuk menjalankan sistem dari Dinas Pendidikan Kabupaten Karo dengan baik, maka diperlukan adanya kinerja yang optimal dari pegawainya. Berhasil atau tidaknya tujuan organisasi ditentukan oleh faktor Sumber Daya Manusia yang ada. Dinas Pendidikan Kabupaten Karo selalu melalukan penilaian terhadap kinerja pegawai setiap tahunnya secara periodik, penilaian kerja itu sendiri dilakukan untuk mengetahui dan mengukur kinerja pegawai.

Dari hasil pengamatan dan wawancara penulis dengan Kepala Dinas Pendidikan Kabupaten Karo, ditemukan adanya penyimpangan mengenai kedisiplinan para pegawai yang tampak dari berulangnya terlambat dan kurang cekatannya dalam pengerjaan tugas yang diberikan, disamping itu sedikit sekali pegawai yang mempunyai inisiatif untuk mengambil tugas atau menggantikan rekan kerja, bahkan menyelesaikan tugas yang dilimpahkan oleh atasan apabila mereka tidak ada ditempat kerja atau mempunyai kepentingan lain. 
Selain itu juga didukung dari hasil wawancara di lapangan dengan beberapa pegawai bahwa ada beberapa pegawai yang menyimpang dengan pergi pada saat waktu bekerja untuk memenuhi kepentingan pribadi, dengan berbagai alasan pesta kerabat, kesekolah anak, dan kembali tidak tepat waktu.

Dalam pengamatan peneliti di lapangan juga mendapatkan kurangnya lingkungan kerja yang memadai untuk mendukung proses kerja pegawai seperti contohnya meja yang saling berdekatan, ruang kerja sempit dan tanpa AC hal mengakibatkan penerangan dan sirkulasi udara kurang maksimal dan mengganggu kenyamanan pegawai serta ada beberapa pedagang yang bolak-balik membuat suasana kurang tenang atau mengganggu konsentrasi pegawai yang sedang bekerja.

Mengacu kepada Peraturan Pemerintah No. 53 Tahun 2010 mengatur tentang disiplin Pegawai Negeri Sipil, maka salah satu pihak yang sangat berperan dalam penegakan disiplin Pegawai Negeri Sipil adalah atasan, terutama atasan langsung. Dari hasil wawancara yang dilakukan terhadap Kepala Dinas Pendidikan Kabupaten Karo juga mengindikasikan bahwa masih lemahnya kedisiplinan pegawai Dinas Pendidikan Pendidikan Kabupaten Karo.

Dari hasil observasi di lapangan juga ditemukan pelanggaran kedisplinan saat dilakukan apel rutin dimana masih banyak pegawai yang saling mengobrol satu sama lain. Apel sendiri merupakan salah satu kegiatan wajib yang diterapkan oleh pimpinan Dinas Pendidikan Pendidikan Kabupaten Karo sebagai sarana pelaporan kinerja pegawai dan pembinaan amanat yang dilaksanakan pada setiap hari senin pagi. Hal ini mengindikasikan kurangnya kedisiplinan pegawai terhadap kehadiran, ketaatan pada peraturan kerja, ketaatan pada standar kerja, tingkat kewaspadaan tinggi dan bekerja etis yang ada di Dinas Pendidikan Kabupaten Karo.
Dari latar belakang yang penulis sampaikan, maka penulis membuat suatu rumusan masalah yaitu :
1. Apakah lingkungan kerja berpengaruh terhadap kinerja pegawai Dinas Pendidikan Kabupaten Karo?

2. Apakah disiplin kerja berpengaruh terhadap kinerja pegawai Dinas Pendidikan Kabupaten Karo?

3. Apakah lingkungan kerja dan disiplin kerja berpengaruh secara simultan terhadap kinerja pegawai Dinas Pendidikan Kabupaten Karo?

\section{URAIAN TEORITIS}

\section{A. Landasan Teori}

\section{Lingkungan Kerja}

Lingkungan kerja termasuk faktor penting dalam meningkatkan kinerja karyawan. Hal ini dikarenakan lingkungan kerja mempunyai dampak langsung terhadap karyawan di dalam menyelesaikan pekerjaan yang pada akhirnya akan meningkatkan kinerja organisasi. Dalam situasi lingkungan kerja dikatakan baik apabila pegawai dapat melaksanakan kegiatan secara optimal, sehat, aman, dan nyaman. Oleh karena itu penetapan dan penciptaan lingkungan kerja yang baik akan sangat menentukan keberhasilan pencapaian tujuan organisasi.

"Lingkungan kerja merupakan keseluruhan alat perkakas dan bahan yang dihadapi lingkungan sekitar di mana seseorang bekerja, metode kerja serta pengaturan kerjanya dilakukan perseorangan maupun kelompok" (Sadarmayanti, 2011:182).

Ishak dan Tanjung, (2013:15) menarik kesimpulan sebagai berikut : Adapun manfaat lingkungan kerja adalah menciptakan gairah kerja, sehingga produktivitas dan prestasi kerja meningkat. Sementara itu, manfaat yang diperoleh karena bekerja dengan orang-orang yang termotivasi adalah pekerjaan dapa diselesaikan dengan tepat. Yang artinya pekerjaan diselesaikan sesuai standar yang benar dan dalam skala waktu yang 
ditentukan. Prestasi kerjanya akan dipantau oleh individu yang bersangkutan, dan tidak akan menimbulkan terlalu banyak pengawasan serta semangat juangnya akan tinggi.

Sadarmayanti, (2011:184), adapun indikator daripada lingkungan kerja adalah sebagai berikut : 1) Suasana kerja; 2) Hubungan dengan rekan kerja; 3) Hubungan antara bawahan dengan pimpinan; dan 4) Tersedianya fasilitas untuk pegawai.

\section{Disiplin Kerja}

Mangkuprawira

mengemukakan bahwa : Kedisiplinan karyawan adalah sifat seseorang karyawan yang secara sadar mematuhi aturan dan peraturan organisasi tertentu. Kedisiplinan sangat mempengaruhi kinerja karyawan dan perusahaan. Kedisiplinan seharusnya dipandang sebagai bentuk-bentuk latihan bagi karyawan dalam melaksanakan aturan-aturan perusahaan. Semakin tinggi disiplin kerja maka semakin tinggi kinerja karyawan dan pengembangan terhadap perusahaan.

Hasibuan (2011:193) mengemukakan bahwa : Kedisiplinan merupakan kesadaran dan kesediaan seseorang menaati semua peraturan perusahaan dan norma-norma sosial yang berlaku. Jadi kedisiplinan merupakan kunci keberhasilan suatu perusahaan dalam mencapai tujuan. "Disiplin sebagai suatu kekuatan yang berkembang didalam tubuh karyawan dan menyebabkan karyawan dapat menyesuaikan diri dengan sukarela pada keputusan, peraturan dan nilai-nilai tinggi dari pekerjaan dan perilaku" (Sutrisno, 2010:87).

Dari beberapa pendapat diatas penulis dapat mengambil kesimpulan bahwa disiplin harus selalu ditegakkan dalam suatu organisasi perusahaan, karena tanpa ada dukungan disiplin pegawai yang baik suatu perusahaan akan mengalami hambatan dalam mencapai tujuannya. Jadi disiplin itu merupakan kunci keberhasilan dalam mencapai suatu tujuan. Disamping itu disiplin juga merupakan bentuk pelatihan yang berusaha memperbaiki dan membentuk pengetahuan, sikap dan perilaku karyawan.

\section{Kinerja}

Novia (2021:1) mengatakan bahwa : "Hasil kerja yang dicapai seseorang dalam menyelesaikan tanggung jawabnya merupakan pengertian dari kinerja. Tingkat keberhasilan seseorang dalam menjalankan tugas secara keseluruhan di periode tertentu disebut juga dengan kinerja. Penyelesaian tugas dan tanggung jawab oleh sekelompok orang dalam suatu organisasi dapat juga disebut dengan kinerja."

Sedangkan Syamsir (2013:74) mengatakan bahwa kinerja adalah : "Kuantitas atau kualitas kerja inividu atau sekelompok organisasi dalam menjalankan tujuannya". Oleh sebab itu, dapat disimpulkan bahwa kinerja karyawan adalah prestasi kerja atau hasil kerja, baik kualitas yang dicapai SDM dengan wewenang dan tanggung jawab masingmasing untuk kebutuhan organisasi dalam upaya pencapaian tujuan perusahaan.

Indikator mengukur kinerja karyawan secara individu terdapat lima yang dikembangkan oleh Becker \& Klimoski (2009), yaitu: 1) Kualitas; 2) Kuantitas; 3) Sikap; 4) Kerjasama; 5) Komunikasi.

\section{B. Kerangka Pemikiran}

Berdasarkan teori sebelumnya, maka dapat digambarkan kerangka pemikiran sebagai berikut :

Gambar : 1 Kerangka Pemikiran

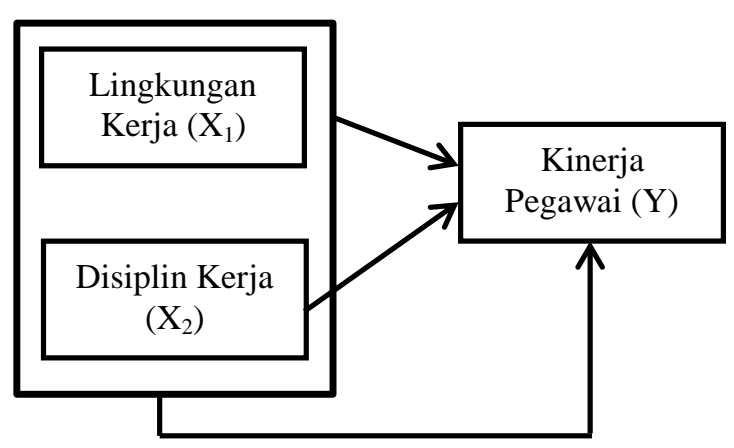


Sumber : Data Diolah Oleh Peneliti, Tahun 2020

\section{Hipotesis}

Dari landasan teori tersebut di atas, pendapat maupun konsep berpikir yang telah disebutkan diatas maka dapat dirumuskan hipotesis penelitiannya sebagai berikut :

1. Terdapat pengaruh lingkungan kerja terhadap kinerja pegawai Dinas Pendidikan Kabupaten Karo.

2. Terdapat pengaruh disiplin kerja terhadap kinerja pegawai Dinas Pendidikan Kabupaten Karo.

3. Terdapat pengaruh lingkungan kerja dan disiplin kerja secara simultan terhadap kinerja pegawai Dinas Pendidikan Kabupaten Karo.

\section{METODE PENELITIAN}

\section{A. Populasi dan Sampel}

Populasi merupakan kumpulan dari masing-masing elemen yang berbentuk peristiwa, hal atau orang yang memiliki karakteristik serupa yang menjadi pusat perhatian peneliti, karenanya dipandang sebagai semesta penelitian, Adapun jumlah populasi dalam penelitian ini yaitu sebanyak 42 orang pegawai di Dinas Pendidikan, Kabupaten Karo.

Sampel adalah bagian dari populasi.Jumlah sampel yang digunakan dalam penelitian ini diambil dari jumlah populasi.Teknik pengambilan sampel yang digunakan dalam penelitian ini yaitu menggunakan Full Random Sampling, yang mana jumlah sampel dalam penelitian ini yaitu berjumlah 42 responden, diambil dari jumlah populasi.

\section{B. Metode Pengumpulan Data}

\section{Penelitian Kepustakaan (Library Research)}

Penelitian kepustakaan adalah landasan teori untuk melakukan analisis data, yang mana penelitian ini menggunakan buku-buku, internet, data perusahaan dan bahan lain yang berkaitan dengan masalah yang akan dibahas, penelitian ini dilakukan dengan cara mempelajari literatur-literatur yang termasuk bahan-bahan perkuliahan, tulisan ilmiah yang berfungsi sebagai alat pedoman dengan menggunakan metode dokumentasi yaitu mencari data atau variable berupa catatan, buku, dansebagainya

\section{Penelitian Lapangan (Field Research)}

Penelitian lapangan adalah teknik pengambilan data dengan secara langsung ke objek penelitian untuk memperoleh data-data yang dibutuhkan. Adapun teknik pengumpulan data yang dilakukan yaitu :
a. Kuesioner
b. Wawancara
c. Observasi

\section{Metode Analisis Data dan Uji Hipotesis}

\section{Analisis Regresi Liniear Berganda}

Analisis regresi linear berganda adalah metode statistic yang berfungsi untuk menguji hubungan sebab akibat antara variable bebas terhadap variable terikat. Berikut rumusan analisis regresi linear berganda

$$
\begin{array}{ll}
\mathrm{Y}=\mathrm{a}+\mathrm{b}_{1} \mathrm{X}_{1}+\mathrm{b}_{2} \mathrm{X}_{2}+\mathrm{e} \\
\text { Dimana } \\
\mathrm{Y} & : \text { Kinerja pegawai } \\
\mathrm{a} & : \text { Konstanta } \\
\mathrm{b}_{1}, \mathrm{~b}_{2} & : \text { Koefisien regresi } \\
\mathrm{X}_{1} & : \text { Lingkungan kerja } \\
\mathrm{X}_{2} & : \text { Disiplin kerja } \\
\mathrm{e} & : \text { Term of error }
\end{array}
$$

\section{Uji t}

Uji $\mathrm{t}$ digunakan untuk melihat apakah variabel bebas yaitu variabel Lingkungan Kerja $\left(\mathrm{X}_{1}\right)$ dan Disiplin Kerja $\left(\mathrm{X}_{2}\right)$, berpengaruh positif dan signifikan terhadap variabel Kinerja Pegawai (Y). Model hipotesis yang digunakan dalam uji $\mathrm{t}$ ini adalah :

a. Jika $t_{\text {hitung }}>t_{\text {tabel }}$, dan signifikansi $<0,05$ maka hipotesis diterima, ada pengaruh variable bebas terhadap variable terikatnya. 


\section{Uji F}

b. Jika $t_{\text {hitung }}<t_{\text {tabel }}$, dan signifikansi $>0,05$ maka hipotesis ditolak, tidak ada pengaruh variable bebas terhadap variable terikatnya.

Untuk melihat apakah variabel bebas, yaitu variabel Lingkungan Kerja $\left(\mathrm{X}_{1}\right)$ dan Disiplin Kerja $\left(\mathrm{X}_{2}\right)$ secara bersama-sama berpengaruh terhadap variabel terikat yaitu Kinerja (Y). Model hipotesis yang digunakan dalam Uji $\mathrm{F}$ adalah :

a. Jika $\mathrm{F}_{\text {hitung }}>\mathrm{F}_{\text {tabel, }}$, dan signifikansi < 0,05 maka hipotesis diterima, ada pengaruh variable bebas secara bersama-sama terhadap variable terikatnya.

b. Jika $F_{\text {hitung }}<\mathrm{F}_{\text {tabel }}$, dan signifikansi $>$ 0,05 maka hipotesis ditolak, tidak ada pengaruh variable bebas secara bersama-sama terhadap variable terikatnya.

\section{Koefisien Determinan $\left(R^{2}\right)$}

Koefisien determinan ini dipakai supaya dapat mengetahui besaran pengaruh variabel-variabel bebas memiliki pengaruh terhadap variabel yang terikat. Nilai koefisien determinan ditentukan dengan nilai adjusted $\mathrm{R}$ square. Koefisien determinan $\left(\mathrm{R}^{2}\right)$ intinya mengukur seberapa jauh kemampuan model dalam menjelaskan variasi variabel dependen. Nilai koefisien determinan adalah antara 0 (nol) dan 1 (satu).

\section{HASIL DAN PEMBAHASAN}

\section{A. Analisis Regresi Linier Berganda}

Analisis ini berguna untuk mengetahui pengaruh antar variabel terikat secara individu terhadap variabel bebas tertentu dapat dilihat dari Unstandardized Coefficients.

Tabel 1 : Analisis Regresi Linier Berganda

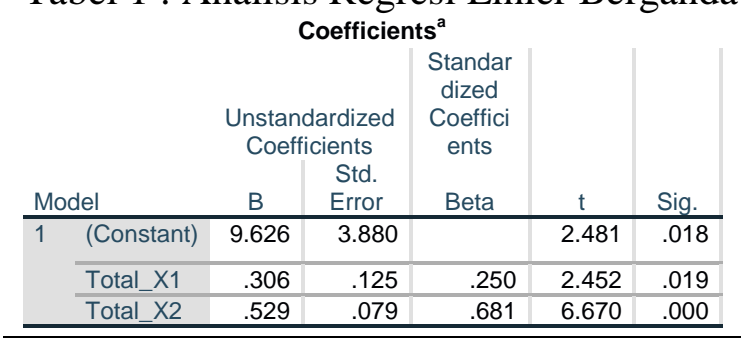

a. Dependent Variable: Total $Y$

Sumber : Data diolah peneliti, Tahun 2020

Berdasarkan Tabel 1 hasil pengolahan persamaan regresi pada tabel Unstandardized Coefficients diperoleh hasil persamaan regresi berganda :

$$
\mathrm{Y}=9,626+0,306 \mathrm{X} 1+0,529 \mathrm{X} 2
$$

Dari persamaan tersebut, maka dapat dijelaskan bahwa :

1. Jika diasumsikan lingkungan kerja (X1) dan disiplin kerja (X2) bernilai 0 , maka nilai kinerja pegawai (Y) adalah sebesar constanta atau 9,626.

2. Pada persamaan juga terdapat nilai koefisien regresi variabel lingkungan kerja (X1) terhadap variabel kinerja (Y) sebesar 0,306, dan pada variabel disiplin kerja (X2) terhadap kinerja (Y) sebesar 0,529. Nilai koefisien ini memiliki arti bahwa jika lingkungan kerja (X1) mengalami kenaikan satu satuan maka kinerja pegawai akan mengalami peningkatan sebesar 0,306. Dan jika variabel disiplin kerja (X2) mengalami kenaikan satu satuan maka kinerja pegawai akan mengalami peningkatan sebesar 0,529.

\section{B. Uji Hipotesis \\ 1. Uji t (Uji Parsial)}

Uji t untuk menguji secara parsial masing-masing variable yang dilihat pada tabel coefficients pada kolom thitung, dimana jika nilai $t$ hitung $>t$ tabel pada Sig $<0,05$, maka Ha diterima, sehingga disimpulkan bahwa variabel independen berpengaruh signifikan terhadap variabel dependen. Dan jika nilai $t$ hitung $<\mathrm{t}$ tabel pada Sig > 0,05, maka H0 diterima, maka disimpulkan bahwa variabel independen tidak berpengaruh signifikan terhadap variabel dependen.

Tabel 2 : Uji t

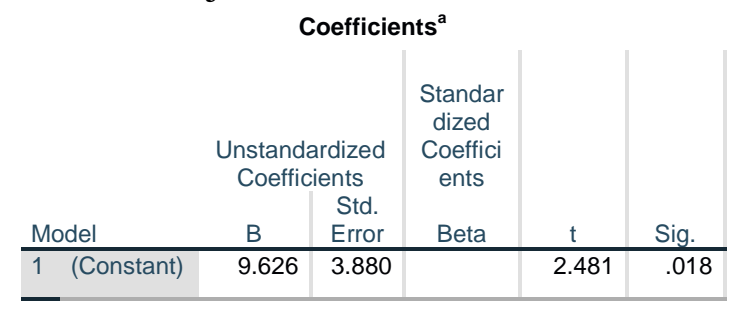




\begin{tabular}{c|c|c|c|c|c|}
\hline Total_X1 & .306 & .125 & .250 & 2.452 & .019 \\
\hline Total_X2 & .529 & .079 & .681 & 6.670 & .000 \\
\hline \multicolumn{2}{l}{ a. Dependent Variable: Total_Y }
\end{tabular}

Sumber : Data diolah peneliti, Tahun 2020

Dapat dilihat dari tabel 2 diatas, maka dapat dijelaskan hasil pengujian hipotesis dalam penelitian ini :

a) Lingkungan kerja berpengaruh positif dan signifikan terhadap kinerja pegawai pada Dinas Pendidikan Kabupaten Karo. Hal ini dapat dibuktikan dengan nilai diketahui nilai $t_{\text {hitung }}(2,452)$ lebih besar dari nilai $t_{\text {tabel }}(2,015)$. Disamping itu, nilai signifikansinya sebesar 0,019 lebih kecil dari 0,05.

b) Disiplin kerja berpengaruh positif dan signifikan terhadap kinerja pegawai pada Dinas Pendidikan Kabupaten Karo. Hal ini dapat dibuktikan dengan nilai diketahui nilai $t_{\text {hitung }}(6,670)$ lebih besar dari nilai $t_{\text {tabel }}(2,015)$. Disamping itu, nilai signifikansinya sebesar 0,000 lebih kecil dari 0,05.

\section{Uji F (Uji Simultan)}

Uji F (Uji Simultan) digunakan untuk melihat apakah variabel bebas, yaitu variabel Lingkungan Kerja $\left(\mathrm{X}_{1}\right)$ dan Disiplin Kerja $\left(\mathrm{X}_{2}\right)$, secara bersama-sama berpengaruh terhadap variabel terikat yaitu Kinerja Pegawai (Y).

Tabel 3 : Uji F pegawai, artinya hipotesis yang diajukan dapat diterima.

\section{Uji Koefisien Determinasi $\left(\mathbf{R}^{2}\right)$}

Analisis yang digunakan adalah regresi berganda, maka yang digunakan adalah nilai $R$, yang mana untuk mengetahui seberapa jauh kemampuan model dalam menerangkan variasi variabel dependen, yaitu koefisien determinasi adalah antara 0 (nol) dan 1 (satu). Nilai yang mendekati 1 (satu) berarti variabelvariabel independen memberikan hampir semua informasi yang dibutuhkan untuk memprediksi variasi variabel dependen. Berikut tabel hasil uji koefisien determinasi :

Tabel 4 : Koefisien Determinasi

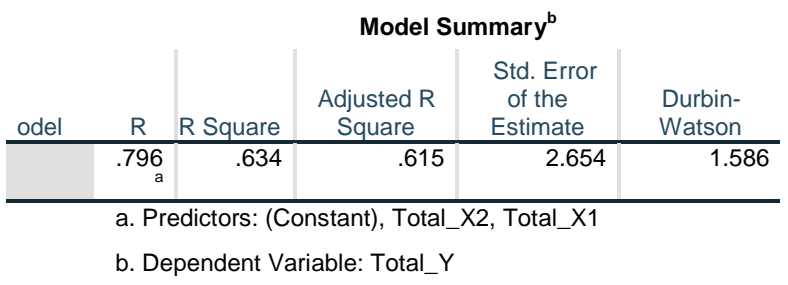

Sumber : Data diolah peneliti, Tahun 2020

Berdasarkan Tabel 4 diatas, maka dapat diketahui nilai Adjusted $R$ Square sebesar 0,634. Nilai ini memiliki arti bahwa variabel terikat (kinerja pegawai) dipengaruhi oleh kombinasi dari variabel lingkungan kerja dan disiplin kerja sebesar $63,4 \%$, sedangkan sisanya sebesar $36,6 \%$ dipengaruhi oleh faktor lain yang tidak diteliti dalam penelitian ini.

\section{Pembahasan}

Berdasarkan hasil analisis yang telah dilaksanakan, diketahui bahwa lingkungan kerja berpengaruh terhadap kinerja pegawai pada Dinas Pendidikan Kabupaten Karo. Hal ini dapat dibuktikan dengan nilai $t_{\text {hitung }}(2,452)$ lebih besar dari nilai $t_{\text {tabel }}$ $(2,015)$, dan nilai signifikansinya sebesar 0,019 lebih kecil dari 0,05.

Hasil penelitian ini sesuai dengan apa yang dikemukakan oleh Budi W. Soetjipto (2014:87), bahwa pengaruh lingkungan kerja adalah segala sesuatu hal atau unsur-unsur yang dapat mempengaruhi secara langsung maupun 
tidak langsung terhadap organisasi atau perusahaan yang akan memberikan dampak baik ataupun buruk terhadap kinerja karyawan".

Penelitian ini didukung oleh hasil penelitian Shalahuddin (2017), dimana lingkungan kerja berpengaruh positif dan signifikan secara parsial terhadap kinerja pegawai Dinas Kependudukan dan Pencatatan Sipil Kabupaten Paser karena mempunyai nilai t hitung $>\mathrm{t}$ tabel $(3,582>$ $1,661)$ dan probabilitas signifikansinya $0,001<0,05$

Hipotesis kedua yang diajukan dalam penelitian ini juga dapat diterima, dimana terdapat pengaruh positif dan signifikan disiplin kerja terhadap kinerja pegawai Dinas Pendidikan Kabupaten Karo. Hal ini dapat dibuktikan dengan nilai $t_{\text {hitung }}$ $(6,670)$ lebih besar dari nilai $t_{\text {tabel }}(2,015)$, dan nilai signifikansinya sebesar 0,000 lebih kecil dari 0,05.

Hasil penelitian ini sesuai dengan apa yang dikemukakan oleh Sutrisno (2010:87), bahwa disiplin sebagai suatu kekuatan yang berkembang didalam tubuh karyawan.

Hasil penelitian ini juga didukung oleh hasil penelitian yang dilakukan oleh Vinie Anuary Putri (2015), bahwa disiplin kerja berpengaruh positif dan signifikan terhadap kinerja pegawai Pada Kantor Dinas Pekerjaan Umum Kabupaten Tulang Bawang Barat.

Hipotesis ketiga dalam penelitian ini juga dapat diterima, yaitu secara simultan lingkungan kerja dan disiplin kerja berpengaruh positif dan signifikan. Hal ini dapat dibuktikan oleh nilai $\mathrm{F}$ hitung $(33,789)$ lebih besar dari nilai $F$ tabel $(2,83)$, dan nilai signifikansinya sebesar 0,000 lebih kecil dari 0,05. Besarnya pengaruh variabel bebas (lingkungan kerja dan disiplin kerja) terhadap variabel terikatnya (kinerja pegawai) dapat diketahui nilai Adjusted $R$ Square sebesar 0,634. Nilai ini memiliki arti bahwa variabel terikat (kinerja pegawai) dipengaruhi oleh kombinasi dari variabel lingkungan kerja dan disiplin kerja sebesar
$63,4 \%$, sedangkan sisanya sebesar $36,6 \%$ dipengaruhi oleh faktor lain yang tidak diteliti dalam penelitian ini.

Hasil penelitian ini didukung oleh penelitian Vinie Anuary Putri (2015), dimana secara simultan disiplin kerja dan lingkungan kerja berpengaruh positif dan signifikan terhadap kinerja pegawai.

\section{PENUTUP}

\section{A. Kesimpulan}

1. Persamaan regresi linier berganda yang diperoleh dalam penelitian ini adalah: $\mathrm{Y}=9,626+0,306 \mathrm{X} 1+0,529$ $\mathrm{X} 2$, artinya jika terjadi kenaikan pada variabel lingkungan kerja maupun variabel disiplin kerja akan mengakibatkan kenaikan juga pada kinerja pegawai. Demikian juga sebaliknya, jika terjadi penurunan pada variabel lingkungan kerja maupun variabel disiplin kerja akan mengakibatkan penurunan juga pada kinerja pegawai

2. Lingkungan kerja berpengaruh positif dan signifikan terhadap kinerja pegawai pada Dinas Pendidikan Kabupaten Karo. Hal ini dapat dibuktikan dengan nilai diketahui nilai thitung $(2,452)$ lebih besar dari nilai ttabel (2,015). Disamping itu, nilai signifikansinya sebesar 0,019 lebih kecil dari 0,05.

3. Disiplin kerja berpengaruh positif dan signifikan terhadap kinerja pegawai pada Dinas Pendidikan Kabupaten Karo. Hal ini dapat dibuktikan dengan nilai diketahui nilai thitung $(6,670)$ lebih besar dari nilai ttabel $(2,015)$. Disamping itu, nilai signifikansinya sebesar 0,000 lebih kecil dari 0,05.

4. Lingkungan kerja dan disiplin kerja berpengaruh positif dan signifikan terhadap kinerja pegawai pada Dinas Pendidikan Kabupaten Karo. Hal ini dapat dibuktikan oleh nilai F hitung $(33,789)$ lebih besar dari nilai $F$ tabel $(2,83)$, dan nilai 
signifikansinya sebesar 0,000 lebih kecil dari 0,05.

5. Besarnya pengaruh variabel bebas (lingkungan kerja dan disiplin kerja) terhadap variabel terikatnya (kinerja pegawai) sebesar 63,4\%, sedangkan sisanya sebesar $36,6 \%$ dipengaruhi oleh faktor lain yang tidak diteliti dalam penelitian ini.

\section{B. Keterbatasan Penelitian}

Disamping keterbatasan kemampuan, waktu dan biaya yang dimiliki oleh beberapa hal berikut juga menjadi faktor terbatasnya penelitian yang dihasilkan, yaitu :

1. Penelitian ini hanya menggunakan variabel disiplin kerja dan lingkungan kerja dalam memprediksi kinerja pegawai, dimana masih banyak faktor lain yang dapat mempengaruhi kinerja pegawai.

2. Hasil pengisian kuesioner belum menggambarkan keadaan yang sebenarnya disebabkan karena perbedaan persepsi masing-masing responden terhadap setiap item pertanyaan yang diberikan.

3. Sedikitnya jumlah responden yang digunakan, sehingga hasil penelitian belum dapat menggambarkan kondisi yang sebenarnya.

\section{Saran}

Berdasarkan hasil penelitian, penulis memberikan saran sebagai berikut:

1. Pemimipin harus dapat memotivasi pegawai agar pegawai lebih mengedepankan pekerjaan yang seharusnya mereka lakukan.

2. Pimpinan harus dapat mengawasi dan mengevaluasi pegawai yang bekerja tidak sesuai dengan prosedur kerja yang sudah ditentukan, serta mendorong pegawai untuk lebih meningkatkan disiplin kerja agar kinerja pegawai dapat lebih memuaskan.

3. Pimpinan dapat lebih meningkatkan kenyamanan lingkungan kerja pegawai agar para pegawai dapat bekerja lebih baik lagi.

4. Peneliti selanjutnya dapat mengembangkan penelitian ini dengan menambahkan variabel lain yang mempengaruhi kinerja pegawai dan mengembangkan model penelitian dengan melibatkan variabel kondisional sebagai variabel moderasi guna mengetahui variabel yang memperkuat dan memperlemah kinerja pegawai.

\section{DAFTAR PUSTAKA}

Arep, Ishak dan Hendri Tanjung. 2013. Manajemen Sumber Daya Manusia, Penerbit Universitas Trisakti: Jakarta.

Becker, T. E., \& Klimoski, R. J. (2009). A field study of the relationship between The organizational feedback environment and performance. Personnel Psychology, 42(2), 343358.

Budi W.Soetjipto, 2008, Budaya Organisasi dan Perubahan. Penerbit PT. Elex Media Komputindo. Jakarta.

Edy Sutrisno. 2010. Manajemen Sumber Daya Manusia. Edisi Pertama. Cetakan Pertama. Jakarta : Penerbit Kencana

Kaswan. 2012. Manajemen Sumber Daya Manusia untuk Keunggulan Bersaing. Organisasi. Graha Ilmu, Yogyakarta

Keputusan Presiden Nomor 68 tahun 1995, tentang Hari Kerja Di Lingkungan Lembaga Pemerintah

Mangkunegara, Anwar Prabu. 2014. Evaluasi Kinerja SDM. Cetakan Keenam. Bandung: PT. Refika Aditama

Marihot Tua Effendi Hariandja. 2010. Manajemen Sumber Daya Manusia, Edisi Revisi, Cetakan Kedua, PT. Grasindo, Jakarta.

Hasibuan, Malayu. 2011. Manajemen Sumber Daya Manusia. Jakarta: Bumi Aksara 
Patria Agusta Permadi (2019), Pengaruh Disiplin Kerja Dan Lingkungan Kerja Terhadap Kinerja Pegawai (Studi Pada Dinas Pendidikan, Pemuda Dan Olahraga Kota Pekalongan), http://eprints.uny.ac.id/65184/

Peraturan Pemerintah Republik Indonesia Nomor 46 Tahun Tahun 2011 Tentang Penilaian Kinerja Pegawai Negeri Sipil

Peraturan pemerintah Nomor 53 Tahun 2010 tentang Disiplin Pegawai Negeri Sipil

Rivai, dan Basri. 2005. Manajemen Sumber Daya Manusia Untuk Perusahaan, Jakarta: Rajagrafindo Persada

Shalahuddin (2017), Pengaruh Disiplin Kerja Dan Lingkungan Kerja Terhadap Kinerja Pegawai Dinas Kependudukan Dan Pencatatan Sipil Kabupaten Paser, https://ojs.uniskabjm.ac.id/index.php/jurnalattadbir/art icle/view/797

Sedarmayanti. 2011. Manajemen Sumber Daya Manusia. Reformasi Birokrasi dan Manajemen Pegawai Negeri
Sipil, Cetakan Kelima, PT Refika Aditama, Bandung

Silaen, Novia R., et al. KINERJA KARYAWAN. Widina Bhakti Persada Bandung, 2021. https://repository.penerbitwidina.com /publications/344479/kinerjakaryawan\#cite

Sondang Siagian. 2013. Manajemen personalia Manajemen Sumber Daya Manusia. Edisi Ketiga. Jakarta : Ghalia Indonesia

Torang, Syamsir. 2013. Organisasi dan Manajemen (Perilaku, Struktur, Budaya \& Perubahan Organisasi. Alfabeta. Bandung.

Vinie Anuary Putri (2015), Pengaruh Disiplin Kerja Dan Lingkungan Kerja Terhadap Kinerja Pegawai (Studi Pada Kantor Dinas Pekerjaan Umum Kabupaten Tulang Bawang Barat)

Wirawan. 2010. Konflik dan Manajemen Konflik: Teori. Aplikasi, dan Penelitian. Jakarta: Salemba Humanika

Wibowo, 2010. Manajemen Kinerja. Jakarta: Rajawali Press. 